\title{
Asylstrømmen fra Russland til Norge i 2015: Bevisst russisk politikk?
}

\author{
Arild Moe` \& Lars Rowe \\ Seniorforskere, Fridtjof Nansens Institutt, Norge
}

\begin{abstract}
In the autumn of 2015,5500 migrants traveling through Russia along the "Arctic route" applied for political asylum in Norway. Some observers claimed that Russia deliberately channeled migrants towards the north with the purpose of destabilizing Norway and that Russia had changed procedures in their border zone to facilitate the wave of migrants. In this article we briefly discuss the hybrid warfare theory and assess alternative explanations that might account for the sudden increase in migrants. Detailing formal and informal practices in the Norwegian-Russian border regime we argue that Russian practices were not altered in any significant way in 2015, but that the Norwegian side had an incorrect impression of the Russian border regime being more restrictive than it really was. Finland was in a similar situation. The most convincing explanation for the wave of asylum-seekers is the selfinterest of migrants who found a cheaper and less risky route. Both in Norway and Finland the border regimes were tightened as a consequence of the increased migration, however. As a result, their policies became more aligned with Russian priorities.
\end{abstract}

Keywords: migration, hybrid warfare, Russia, border regime, asylum, Norway

Den store strømmen av asylsøkere over grensen mellom Russland og Norge høsten 2015 ble heftig debattert av norske politikere og andre meningsytrere. Først og fremst var mange, naturlig nok, opptatt av hvordan situasjonen skulle håndteres på norsk side. Men et annet spørsmål som kom opp i den norske debatten var hvordan den store strømmen av flyktninger oppsto så plutselig. I løpet av noen hektiske måneder søkte 5500 mennesker asyl ved grensestasjonen på Storskog. Flere deltakere i ordskiftet var sikre på at dette var en strøm som var styrt av russiske myndigheter. De antok at Russland ønsket å straffe Norge for landets tilslutning til de økonomiske sanksjonene. Enkelte hevdet at flyktningstrømmen måtte ses som et ledd i en russisk hybridkrig mot Norge - flyktningene ble kanalisert mot Norge for å destabilisere landet, het det. ${ }^{1}$

\footnotetext{
^Kontaktinformasjon: Arild Moe. Email: arild.moe@fni.no

${ }^{1}$ Oberstløytnant Geir Hågen Karlsen (2015) redegjør for russisk hybridkrigføring og de farer den medfører for Norge. Karlsen tolket senere situasjonen ved Storskog høsten 2015 i lys av russiske 
I denne artikkelen ønsker vi å analysere begivenhetene i de norsk-russiske grensetraktene høsten 2015. Vi vil spesielt vurdere hvorvidt det er sannsynlig at russiske myndigheter sto bak det som skjedde, eller om andre faktorer har større forklaringskraft. Dette er viktige spørsmål. Det dreier seg ikke bare om å forstå hva som var situasjonen ved Storskog høsten 2015. En logisk implikasjon av hybridkrigteorien, hvis den er riktig, er at strømmen av flyktninger vil kunne skrus på igjen når som helst hvis Russland skulle ønske det.

Artikkelen er altså et forsøk på å analysere et spesifikt hendelsesforløp, og forstå hvorfor situasjonen ved Storskog utviklet seg som den gjorde høsten 2015. For å etablere en kronologi, og tolke utviklingen i lys av den, har vi brukt offentlige dokumenter samt russiske, norske og finske mediers dekning av saken. Det spesifikke temaet i artikkelen er i liten grad beskrevet i forskningslitteraturen tidligere. Men når det gjelder bredere vurderinger av dagens russiske strategier er det flere som hevder at de best kan forstås i lys av landets sovjetiske fortid. Forsøk på dette kommer nå fram i akademisk format, se for eksempel Pynnöniemi \& Rácz (2016). Ken Giles (2016) legger vekt på at russisk strategi og merkelappen «hybridkrig» i stor grad må forstås som gammel vin på ny flaske, og viser til den sovjetiske tradisjonen for at desinformasjon og propaganda ledsager militære intervensjoner. Giles er også, som en av denne artikkelens forfattere, opptatt av at dagens Russland i et historisk perspektiv (som strekker seg til godt inn i den førrevolusjonære perioden) er langt nærmere en normaltilstand enn 1990-årenes Russland (Rowe \& Hønneland 2010).

Vi kan ikke avvise at Russland anvender hybride midler mot Norge. Offisielle norske trusselvurderinger har stadige referanser til russiske forsøk på såkalte cyberangrep (Etterretningstjenesten 2016). Vi finner også eksplisitte henvisninger til hybridkrigføringens betydning på russisk side. Den russiske generalstabssjefen Valerij Gerasimov (2013) har offentlig redegjort for ulike ikke-militære virkemidler som i hans øyne kan og bør benyttes i ulike konfliktsituasjoner. Den russiske framferden under urolighetene i Ukraina årsskiftet 2013-2014 og litt senere på Krimhalvøya bar da også preg av å være en krigføring der andre enn rent militære virkemidler ble brukt. Enkelte russiske kommentatorer har pekt på at hybridkrigføringens prinsipper etter disse begivenhetene ikke er reservert det russiske militærvesenet, men at slike virkemidler har blitt en del av allmenn russisk utenrikspolitikk (Vedomosti 2016a).

Teorien om at russiske myndigheter sto bak asyltilstrømningen er basert på en antagelse om at Moskva ønsker å destabilisere Norge og ikke minst at en strøm av asylsøkere over grensen betraktes som et hensiktsmessig virkemiddel for å oppnå dette. Vi gjør ikke her noe forsøk på å analysere russisk politikk mot Norge i bred forstand - det er et annet tema. I stedet går vi inn i saksforholdet «nedenfra» og ser på de konkrete hendelsene ved Storskog i 2015. Hva er den mest troverdige forklaringen på det som skjedde? Dette innebærer at vi må være åpne for at spesifikke

ambisjoner om å svekke Norge, i et radiointervju, se https://radio.nrk.no/serie/dagsnytt-atten/ NMAG03022315/10-11-2015\#t $=10 \mathrm{~m} 43$ s (lesedato 16 juni 2016). En eksplisitt framstilling av hybridkrig-teorien ble presentert av Kjetil Stormark (2015). At flyktningstrømmen var Russlands straff av Norge ble hevdet av Kjell Dragnes (Aftenposten 2015a). 
russiske intensjoner kan være en forklarende faktor, dersom ikke andre forklaringer virker overbevisende.

I tillegg til en forutsetning om russiske intensjoner hvilte teorien om Russlands rolle på to påstander eller observasjoner: For det første mente man å kunne observere en endring i det russiske grenseregimet. Mens russiske myndigheter tidligere holdt tilbake personer uten visum til Norge eller andre Schengen-land, gikk de plutselig over til å slippe alle som kom nordover helt fram til den norske grensebommen.

For det andre observerte man at det ikke var en tilsvarende strøm over grensen til Finland, som også deler grense med Russland i nord, noe som indikerte at Russland fulgte en annen praksis der. Dette kunne tyde på at russiske myndigheter var spesielt ute etter å straffe Norge. Finland er riktignok med på EUs sanksjoner mot Russland, men er dog ikke NATO-medlem.

Begge disse påstandene, at den russiske praksisen overfor Norge ble endret og at finnene «unnslapp» en flyktningstrøm fra Russland, dreier seg altså om empiriske

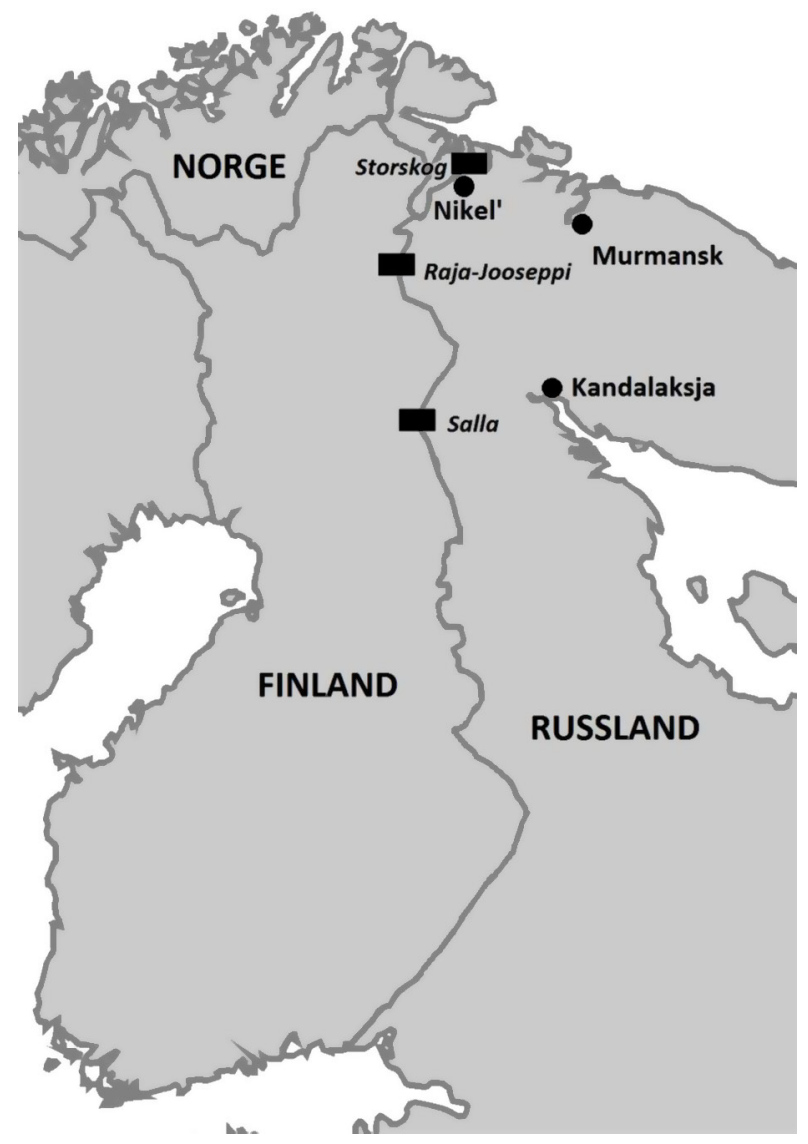

Grensepasseringspunkter fra Russland $i$ Nord-Finland og Norge.

Kilde: Fridtjof Nansens Institutt 
forhold. I prinsippet bør det være mulig å finne ut om de faktisk stemmer med virkeligheten.

I det følgende vil vi derfor se nærmere på tilstrømmingen av asylsøkere slik den forløp høsten 2015 og de tiltak norske og russiske myndigheter iverksatte, samt hvilke interesser russiske myndigheter kunne ha i saken. Deretter vil vi sammenligne med det som skjedde ved de finsk-russiske grenseovergangene med sikte på å identifisere eventuelle forskjeller, før vi oppsummerer. Først skal vi imidlertid gi et kort overblikk over det norsk-russiske grenseregimet etter Sovjetunionens sammenbrudd.

\section{Det norsk-russiske grenseregimet}

Før 1992 var grensen mellom Russland og Norge en «lukket grense» som bare ble åpnet ved spesielle behov. Fra og med januar 1992 har grenseovergangen mellom Russland og Norge ved Storskog i praksis vært åpen. Dette betyr at vanlig ferdsel i begge retninger har vært lovlig forutsatt at den som ferdes innehar de nødvendige dokumentene. Trafikken over grensen vokste fort etter at Russland avskaffet reguleringene av utenlandsreiser hos sine borgere. Svært mange mennesker bosatt i Murmansk-området gjorde handleturer til Kirkenes til en regelmessig foreteelse. Mange nordmenn besøkte også Murmansk, selv om dette tallet var langt lavere. I toppåret 2013 passerte i alt 320000 personer den norsk-russiske grensen (Aftenposten 2014).

Russere som vil til Norge trenger visum og omvendt. Det finnes imidlertid en egen kategori reisende over denne grensen - de som innehar grenseboerbevis. I november 2010 ble det underskrevet en avtale om dette (Grenseboeravtalen 2010). Beviset kan oppnås hvis man har vært fast bosatt nærmere enn 30 kilometer fra riksgrensen på norsk og russisk side i minst tre år. Det er ikke reservert for norske eller russiske statsborgere, og omfatter omkring 9000 mennesker på norsk side og opptil 45000 personer på russisk side. Utstedelse av grenseboerbeviset, som foretas av generalkonsulatene $\mathrm{i}$ henholdsvis Murmansk og Kirkenes, forutsetter at søkeren oppfyller krav som ellers stilles til visumutstedelse, og kan betraktes som et slags permanent visum. Bestemmelsen om grenseboerbevis trådte i kraft 29. mai 2012.

For dem som hverken innehar grenseboerbevis, norsk eller russisk pass eller visum som gir innreisetillatelse til henholdsvis Russland og Norge, finnes det et antall bestemmelser. Utgangspunktet er naturligvis ordinære visumbestemmelser på begge sider, samt internasjonale forpliktelser vedrørende migrasjon de to land måtte være (eller oppleve seg) forpliktet av. I tillegg finnes ulike avtaler og forordninger som er spesifikke for grenseovergangen Storskog/Boris Gleb og praksiser som i hovedsak er utviklet i samarbeid mellom grensekommissærene i de to land. ${ }^{2}$

\footnotetext{
${ }^{2}$ Hovedoppgaven til det norske grensekommissariatet er å påse at Grenseavtalen og øvrige overenskomster med Russland blir overholdt. Kommissariatet er kontaktpunktet mot russiske myndigheter. Selve grensestasjonen Storskog betjenes av politiet, mens grensen bevoktes av Garnisonen i Sør-Varanger. På russisk side er det grensestyrkene, som inngår i den føderale sikkerhetstjenesten (FSB), som har ansvaret for hele grenseområdet så vel som grensestasjonen Boris Gleb.
} 
For det første har vi den såkalte Tilbaketakingsavtalen som trådte i kraft 1 . desember 2008. Avtaleteksten understreker innledningsvis at den «ikke berører rettigheter, forpliktelser eller ansvar som Norge og Den russiske føderasjon har i henhold til folkeretten, (...)» (Tilbaketakingsavtalen 2007). I følge avtalen plikter Russland å ta tilbake personer som innehar en gjeldende oppholdstillatelse hos dem (eller innehadde en slik på det tidspunktet Norge anmodet om tilbaketaking), og som samtidig ikke er innrømmet en tilsvarende oppholdstillatelse i Norge.

Tillatelse til transitt gjennom Russland (eller Norge) skal søkes begrenset til tilfeller der personen faller inn under bestemmelser i det internasjonale rettighetsregimet (artikkel 14) - med andre ord dersom tredjelandsborgeren eller den statsløse personen er utsatt for forfølgelse eller, i dagligtale, er å betrakte som en flyktning. Tilbaketakingsavtalen er, slik den framstår, en praktisk ordning mellom Norge og Russland som skal gjøre utveksling av personer som har krysset fellesgrensen på ulovlig vis mer smidig.

I tillegg til disse formelle bestemmelsene har grenseregimet vært regulert av ytterligere en praksis, som er langt mindre formell, og som har vært gjenstand for gjentatte forhandlinger mellom de to lands grensekommissærer. Denne praksisen ble kjent for den norske offentligheten da grenseinspektør Ulf Mathisen, som har 4 års fartstid ved Grensekommissariatet i Sør-Varanger, gikk ut med sin informasjon i november 2015. ${ }^{3}$ Innsikt i denne praksisen er en forutsetning for å forstå hvordan de to lands grensemyndigheter sammen har håndtert tredjelands borgere og statsløse uten visum til Norge.

Siden 2003 har Norge og Russland gjennomført det som kalles en felles dokumentkontroll av mennesker som vil krysse inn i Norge uten visum. Rent praktisk betyr dette at den russiske grensevakten ved Boris Gleb i sin dokumentkontroll plukker ut tredjelands borgere eller statsløse uten visum til Norge eller et annet Schengen-land. Dokumentene (ikke den reisende selv) blir så overbrakt til tilsvarende kontroll på norsk side (Storskog). I 2012 introduserte Norge en praksis som innebar at det ble lagt inn et orienterende skriv i reisedokumentene før de ble returnert til den visumløse tredjelandsborgeren. Skrivet orienterte om norsk visumkrav. Dette skrivet, og formuleringen det har inneholdt $\mathrm{i}$ ulike perioder, er det helt sentrale elementet $\mathrm{i}$ den følgende redegjørelsen.

Med utgangspunkt i Tilbaketakingsavtalen ville en klar formulering, som fastslo at tredjelands statsborgere eller statsløse uten visum ikke har adgang til Norge, gitt

\footnotetext{
${ }^{3}$ I sin tid ved Grensekommissariatet i Sør-Varanger har Mathisen deltatt på mer enn 150 møter med ulike nivåer i den russiske forvaltningen. Den følgende gjennomgangen av denne mer uformelle, men likevel avgiørende praksisen er i hovedsak basert på grenseinspektør Ulf Mathisens uttalelser 10. november 2015 (NRK Finnmark 2015, Dagsrevyen 2015). De to nyhetssakene inneholder ikke bare Ulf Mathisens uttalelser, men omfatter også kommentarer fra politimester i Øst-Finnmark politidistrikt Ellen Katrine Hætta, professor i jus ved Universitet i Tromsø Peter Ørebech, kommunikasjonsrådgiver i Justis- og beredskapsdepartementet Tonje Torsgård, utenriksminister Børge Brende og statsminister Erna Solberg. Mathisens påstander og tolkning av situasjonen ble delvis tilbakevist av Torsgård, mens de øvrige forholdt seg nøytrale. Unntaket var professor Ørebech, som gikk langt i å bekrefte Mathisens versjon av saken.
} 
russiske grensemyndigheter ryggdekning for å stoppe slike reisende før de kom fram til grensebommen ved Storskog. ${ }^{4}$ Eller, mer presist - russiske grensemyndigheter oppfattet at en restriktiv formulering fra norsk side ville gitt FSBs personale et skriftlig grunnlag for å stoppe migranter uten visum til Norge - ifølge grenseinspektør Mathisen. ${ }^{5}$ Bakgrunnen for hans tolkning av russiske myndigheters oppfatning var at han var til stede ved møter der dette budskapet ble formidlet i klare ordelag fra russisk side av bordet. Hvis norske grensemyndigheter hadde utferdiget en tilstrekkelig tydelig formulering, fortsetter Mathisen, ville altså russiske myndigheter ha kunnet stoppe reisende uten visum til Norge ikke bare ved Boris Gleb - den russiske siden av grensestasjonen i Pasvikdalen - men allerede ved sjekkpunkter på veien til grensen. Russiske grensemyndigheter ønsket en slik formulering, hevder han. Brevet var imidlertid bare formulert som en anbefaling: «For å reise inn i Norge og Schengen er det krav at man må ha visum for innreise. Siden De ikke har et slikt visum vil vi anbefale Dem om å søke visum (...)»(Østfinnmark politidistrikt 2012).

\section{Den russiske grensesonen}

Områdene nær grensen på russisk side er underlagt et særlig regime som er etablert for å sikre ulike militære installasjoner i området mot uønsket innsyn. Områdene oppfattes med andre ord som svært sensitive av russiske myndigheter (Hønneland \& Jørgensen 2007). Graden av myndighetskontroll over bevegelser i området er høy, og understreker det russiske ønsket om å ha oversikt over hvor mange og hvilke personer som til enhver tid befinner seg der. Men mens det i Norge er forventet at russerne utøver streng kontroll på sin side av grensen, har man vært mindre opptatt av de finere detaljer i den russiske reguleringen av grensesonen.

Definisjonen av grensesonen - pogranitsjnaja zona - på russisk side har gjennomgått flere revisjoner i senere år. Generelt er sonen en $15 \mathrm{~km}$ bred stripe langs grensen. I 2006 ble det imidlertid vedtatt regler som unntok blant annet byen Nikel fra sonen (FSB 2006). «Liberaliseringen» var kortlivet. Allerede et år etter kom en ny forordning som igjen inkluderte Nikel. Den 1. oktober 2008 kom så enda en revisjon som inneholdt en rekke unntak fra grensesonen, deriblant Nikel.

\footnotetext{
${ }^{4}$ I NRK-saken refereres det (antakelig feilaktig) til Grenseavtalen, ikke Tilbaketakingsavtalen. Tilbaketakingsavtalen, som i sin tur bygger på Grenseavtalen fra 1949 (som fremdeles er gjeldende), er den overenskomsten som mest detaljert og på en mest oppdatert måte behandler håndteringen av tredjelands borgere og statsløse personer i området. Schengen-avtalen, som innebærer at visum til Norge er å betrakte som en innreisetillatelse til hele Schengen-området, trådte for Norges del i kraft den 25. mars 2001.

${ }^{5}$ Det betyr ikke at denne russiske tolkningen er i tråd med alle norske juristers lesning. Frode Berg, som arbeidet som grenseinspektør ved Grensekommissariatet i Sør-Varanger i 24 år før han ble pensjonert, og som har blitt leid inn på timebasis for å assistere i ulike prosjekter, har latt oss forstå at det forholdt seg annerledes for ulike jurister på regionalt og sentralt nivå i Norge. Hovedpoenget her er imidlertid ikke hvordan Tilbaketakingsavtalen skal tolkes, eller hvordan den ble tolket av norske myndigheter, men hvordan russiske tjenestemenn tolket den.
} 
Fram til 2008 hadde kontrollstasjonen i Titovka markert inngangen til grensesonen hvor man måtte ha spesiell tillatelse for å bevege seg. Nå var deler av dette området kun definert som grensenær sone (prigranitsjnaja zona) (Murmanskij Vestnik 2008). ${ }^{6}$ Grensevaktsoldatene sto ved slagbommen som før, men grunnlaget for deres myndighetsutøvelse og formålet med deres nærvær var endret. I henhold til de nye reglene hadde de rett til å kontrollere at reisende hadde med seg gyldig legitimasjon eller pass, noe som kreves i nær-grensesonen, men det var også alt. Med gyldig pass og russisk visum var det nå ikke noe i veien for at en utlending kunne reise til Nikel og ta inn på hotell der og eventuelt reise videre. Tidligere hadde grensevaktene hatt mulighet til å stoppe reisende ut fra en rekke kriterier. Etter hvert ble kontrollposten i Titovka helt fjernet og erstattet med mobile kontroller over en lengre veistrekning. Også i de generelle reglene for russiske grensesoner skjedde det endringer. I nye regler fra 2012 ble FSBs mulighet til å nekte gjennomreise i grensesonen etter eget forgodtbefinnende betydelig begrenset, for ikke å si avskåret (FSB 2012).

Hovedtendensen i utviklingen av grenseregimet på russisk side har vært liberalisering. Vi vil tro at økonomiske og sosiale grunner har vært en drivkraft. Etableringen av grenseboerbeviset trekker i samme retning. Men samtidig mener vi det er rimelig å anta at sikkerhetsmyndighetene, inkludert den russiske grensevakttjenesten, har et iboende og for så vidt helt legitimt kontrollbehov, og at liberaliseringer av grenseregimet delvis er blitt kompensert med nye kontrolltiltak. Etter at grenseboeravtalen ble undertegnet ble det for eksempel etablert en ny kontrollpost, ved vannet Salmijärvi på veien mellom grensebyen Nikel og grensestasjonen ved Boris Gleb (Khibiny.com 2012). Kontrollposten ved Titovka ble også satt opp igjen. Vi må imidlertid skille mellom kontrolltiltak og det foreliggende grunnlaget for å hindre folk i å reise gjennom grensesonen. For mens kontrollmuligheten fortsatt er sterk er det rettslige grunnlaget for å stoppe folk faktisk blitt svekket. Det er nettopp i lys av dette forhold vi forstår russiske forsøk på å overbevise norske grensemyndigheter om å forsterke formuleringen i skrivet som orienterer tredjelands borgere eller statsløse uten visum til Norge om hvilke begrensninger som ligger i det norske asylregimet. Vi mener det er sannsynlig at russiske grensemyndigheter har søkt å kompensere for liberaliseringen på egen side ved å oppmuntre til norske restriksjoner.

Dette er nyanser som er blitt lite påaktet fra norsk side. Det rådende bildet, $\mathrm{i}$ Norge så vel som internasjonalt, har vært av et strengt russisk grenseregime som etter eget forgodtbefinnende kunne nekte uønskede personer adgang til grensen. Men så var det altså allikevel noen som prøvde seg. Østfinnmark politidistrikts egen statistikk for perioden fra 2003 til og med første kvartal 2015 viser at tallene var lave, dog med så mange som 53 i toppåret 2003. I 2013, som var det året med lavest

\footnotetext{
${ }^{6}$ Forskjellen på prigranitsjnaya zona (grensenær sone) og pogranitsjnaja zona (grensesone) er større juridisk sett enn språklig sett. I det som er definert som grensesone har grensemyndighetene (FSB) uinnskrenket politimyndighet. I den grensenære sonen, som er en løsere definert kategori, har grensemyndighetene i utgangspunktet bare kontrollmyndighet. Dette innebærer at de har rett til å sette opp sjekkpunkter for å kontrollere reisendes identitet. Om grensemyndighetene mener å kunne dokumentere at en reisende har til hensikt å bryte reglene i grensesonen, har de også rett til å avskjære vedkommende fra å bevege seg inn i den (Zakon 1993).
} 
aktivitet, kom kun 3 personer. Samlet gir tallene et gjennomsnitt på 16,5 personer per år i perioden 2003-2014 (Østfinnmark politidistrikt 2015). Et så lite antall utgjorde ingen utfordring for Norge og det virker ikke som norske myndigheter hadde ønske om å gi russiske grensevakter noen form for mandat til å stoppe disse migrantene, noe den russiske siden altså bad om. Men samtidig stolte man implisitt på at det russiske grenseregimet ville forhindre at enkelttilfellene av migranter ble til noe mer. Denne forventningen viste seg høsten 2015 å være urealistisk. En konsekvens var, som vi skal se, en ny vilje på norsk side til å imøtekomme russiske ønsker.

\section{Tilstrømmingen av asylsøkere i 2015}

Fra mai til juni 2015 kom 50 migranter uten visum fram til grensen og ble sluppet inn i Norge (Murmanskij Vestnik 2015a). Mot slutten av august hadde tallet økt til 133. Først da begynte norsk presse å vise interesse (Aftenposten 2015b). Siden strømmen var temmelig begrenset sammenlignet med tilstrømmingen over svenskegrensen i sør, ble opplysningen om denne «tungvinte» ruten først framstilt nærmest som en kuriositet, noe som ble understøttet av den sære transportformen. Fordi russiske myndigheter krevde at transporten over grensen måtte skje «på hjul» og migrantene ikke hadde tilgang til bil, hadde de skaffet seg sykler. Sykkeltrafikken fra Nikel til Storskog gav gode historier og bilder som snart spredte seg internasjonalt (Reuters 2016), også gjennom russiske TV-kanaler som vises i Syria (Murmanskij Vestnik 2015b).

Allerede i begynnelsen av september ble det rapportert i regionale media $\mathrm{i}$ Russland at det var stor etterspørsel etter sykler i Nikel (Murmanskij Vestnik 2015a). Fram til sommeren hadde asylsøkere kunnet kjøre over grensen i drosje, men i slutten av august begynte norsk politi å true russiske sjåfører med bøter og utestengelse fra Norge $\mathrm{i}$ tre år dersom de fraktet passasjerer uten visum over grensen (Aftenposten 2015b).

Også på russisk side vakte trafikken over grensen økende oppmerksomhet. Russiske media framhevet at migranter med turistvisum til Russland fritt kunne bevege seg inn i grenseområdet såfremt de hadde midler til livets opphold. En offisiell representant for grensevakten uttalte til avisen Kommersant at «[v]i har ingen anmerkninger mot disse menneskene. Alt er i orden med deres russiske visa, Schengen-visum har de ikke, men det er de norske grensevaktenes bekymring» (Kommersant 2015a). Selve reiseopplegget ble klart beskrevet: Fly eller tog til Murmansk, drosje til Nikel til en pris av minst 10000 rubler (i september 2015 omkring 1200 kroner) og sykkel til et par tusen kroner. En drosje fra Nikel til grensen (med sykkel på taket) kunne koste opptil 500 USD (Murmanskij Vestnik 2015b). Transportørene kunne også tilby tolketjeneste, mot betaling (Murmanskij Vestnik 2015a). Noen migranter oppgav en totalpris på reisen fra Midtøsten og fram til grensen på 2500 USD. Til sammenlikning ble reise via Hellas oppgitt til å kunne koste 18000 USD (Kommersant 2015a). Priseksemplene viser to ting: At ruten var svært billig sammenlignet med alternativene, men også at det var mye penger å tjene på å selge tjenester til migrantene. 
Det er innlysende at denne typen informasjon, som ble spredd ikke bare gjennom media, men også fra dem som allerede hadde kommet over grensen, ville tiltrekke flere migranter. Mens det i de første rapportene sto at de kom mer eller mindre direkte fra Syria, ble det i slutten av september rapportert at flere hadde lange opphold i Russland bak seg. Trafikken til og over grensen hadde nå fått et organisert preg. Allerede i slutten av september ble det meldt om en flyankomst til Murmansk med 30 syrere om bord (Kommersant 2015a). Migrantene ble møtt av sjåfører på flyplassen i Murmansk, riktignok på en fordekt måte, og kjørt med buss eller bil, gjerne via en sportsbutikk i Murmansk som tilbød sykler, og videre enten til hotellet i Nikel, eller nesten helt fram til grensen (Murmanskij Vestnik 2015b). For reisende med slik transport gjensto bare et kort strekk som måtte tas på medbrakt sykkel.

Ved inngangen til oktober 2015 hadde 1200 søkt asyl på grensen. I midten av oktober tok utenriksminister Børge Brende saken opp med sin russiske motpart Sergej Lavrov og spurte hva som foregikk og hvilken status flyktningene hadde i Russland (Kommersant 2015b). Russiske myndigheter tilbakeviste at de hadde initiert flyktningstrømmen og hevdet at russiske grensevakter ikke hadde fullmakt til å kontrollere tilstedeværelse av gyldig visum eller andre innreisepapirer til andre land hos utlendinger (TASS 2015). Strømmen fortsatte å øke. I oktober befant i gjennomsnitt 450 migranter seg i Nikel hver dag. Hotellene var fulle og mange leide rom privat. Det høyeste antallet grensepasseringer av asylsøkere inntraff 4 . november, med 196 mennesker. Trafikken ble deretter kraftig redusert og tørket helt inn i begynnelsen av desember (Murmanskij Vestnik 2015c). Da hadde omkring 5500 mennesker søkt asyl på grensen til Norge.

\section{Norsk og russisk respons}

En viktig ting som skjedde i november var at en ny prosedyre på norsk side av grensen ble introdusert. Endringene trådte i kraft den 7. november. Reisedokumentene norsk grensevakt mottok fra sine russiske kolleger skulle nå registreres og kontrolleres på stedet mot diverse databaser før de ble returnert til personer som sto på russisk side av grensen uten visum. Sammen med papirene ble det nå lagt inn en ny versjon av brevet fra norske myndigheter. Nå het det at «Ditt reisedokument (pass) inneholder ikke visum til Norge, og gir derfor ikke adgang til innreise eller opphold i Norge» (NRK Finnmark 2015). Dette var en strammere formulering enn i brevet tredjelandsborgere uten visum til Norge tidligere hadde mottatt, og lå nærmere det den russiske siden tidligere hadde etterlyst. Statsminister Erna Solberg uttalte til NRK i den forbindelse at «[d] et er klart at vi har snakket med russerne om dette lenge og har vært tydelige på at vi ikke ønsker at de skal sende over folk som ikke har et schengen-visum» (NRK Finnmark 2015). Norske myndigheter var altså på glid i spørsmålet om å gi russerne ryggdekning for å stoppe migranter.

Samtidig hadde den norske regjeringen varslet lovendringer som ville legge til rette for hurtigere utsendelse av grunnløse asylsøkere og asylsøkere med opphold i trygt tredjeland. Endringene i loven trådte i kraft 20. november, og 25. november 
begynte en ny instruks å virke. I en ytterligere revidert versjon av brevet til personer uten visum på grensen het det nå:

Ditt reisedokument (pass) inneholder ikke gyldig visum eller annen innreisetillatelse til Norge, og du vil på dette grunnlag nektes adgang til innreise eller opphold i Norge. Ulovlig opphold i Norge vil medføre bortvisning til Russland eller et annet land som du er statsborger av eller har gyldig oppholdstillatelse i (Justis- og beredskapsdepartementet 2015).

Samtidig skulle den russiske grensevakten få et skriv der de ble anmodet om ikke å slippe personer uten gyldig visum til Norge fram til grensen. Med dette var den norske prosedyren helt $\mathrm{i}$ tråd med ønskemålene fra russisk side, slik de allerede $\mathrm{i}$ 2012 ble oppfattet av den norske grenseinspektøren Ulf Mathisen.

Gitt den raske informasjonsspredningen i flyktning- og migrantmiljøene i Russland og opprinnelseslandene, hovedsakelig ved hjelp av sosiale medier, må man anta at denne tilstramningen på norsk side hadde innvirkning på strømmen mot grensen i nord. Det kan likevel spørres om det på russisk side også ble gjennomført endringer som bidro til å avskrekke eller stoppe migranter som hadde tenkt seg over grensen. 13. november ble det meldt at den russiske migrasjonstjenesten hadde igangsatt intensiv identitetskontroll på Sjeremetevo-flyplassen i Moskva for reisende til Murmansk (Nord-News.ru 2015). Dette kunne tyde på tilstramning. Men samtidig het det at utlendinger ikke i noe tilfelle ville bli stoppet så lenge de hadde riktig utfylte dokumenter (Nord-News.ru 2015). Dette indikerte at det foreløpig ikke hadde skjedd dramatiske endringer på russisk side. Men vi vil anta at den korte tiden som var gått siden den norske innstramningen kan forklare at kontrollen i Moskva på dette tidspunktet fulgte tidligere instruks. Det tar tid å endre regler i den russiske forvaltningen.

\section{Russiske interesser}

Hvordan kan man så tolke den russiske responsen på og håndteringen av menneskestrømmen over grensen i nord? Det russiske grenseregimet var blitt liberalisert over tid. Men det skjedde lenge før økningen i migranter langs den arktiske ruten, og det var ikke mange i Norge som hadde registrert det. Det var først da flyktningstrømmen kom at det ble et problem at veien til grensen lå åpen. Som nevnt innledningsvis i denne artikkelen, var det mange i Norge som ikke kunne tro at det var mulig at så mange mennesker kunne ta seg forholdvis lett fram til grensen uten å være hjulpet av russiske myndigheter. Vår gjennomgang viser at det var unødvendig med slik hjelp. Da det begynte å ryktes at veien til grensen lå åpen og at kostnadene og risikoen ved å bruke den «arktiske ruten» var langt mindre enn ved alternativene, var det rasjonelt å velge denne muligheten for dem som hadde anledning. At det var mange private aktører på russisk side som hadde økonomiske interesser $\mathrm{i}$ å hjelpe migrantene med reiseopplegg og overnatting, virker også helt opplagt. Etter at strømmen av asylsøkere over grensen stoppet, ble det meldt at en 
mann med forbindelse til et tungt kriminelt miljø var arrestert i Murmansk for organisering av flyktningers reise gjennom regionen (Nord-News.ru 2016a).

Likevel gjenstår spørsmålet om russiske myndigheter har tilskyndet strømmen over grensen ut fra et ønske om å skade Norge. At korrupte russiske tjenestemenn har skodd seg på flyktningstrømmen er nå en kjent sak. I St. Petersburg ble det avslørt en storstilt svindel regissert av en tidligere medarbeider i utenrikstjenesten. Det ble utstedt fiktive arbeidskontrakter som ga grunnlag for arbeidsvisum til Russland. Mange med slike visa hadde reist til Norge. Migrasjonsmyndighetene i Murmansk oblast henvendte seg til og med til sine kolleger i St. Petersburg fordi så mange av migrantene hadde arbeidstillatelse i mistenkelige firmaer der (Kommersant 2016). Det russiske migrasjonsvesenet er selv blitt anklaget for korrupsjon og ineffektivitet i en slik grad at det ble foreslått å nedlegge hele tjenesten (Vedomosti 2016b). I april 2016 ble det imidlertid bestemt å underlegge den Innenriksministeriet (Vedomosti 2016c). Korrupte tjenestemenns egeninteresser er imidlertid noe annet enn statens politikk.

Spørsmålet som naturlig må stilles er om flyktningstrømmen var i tråd med russiske interesser, slik enkelte har hevdet, og om den var et tjenlig instrument for russisk destabilisering av Norge. Hvilke intensjoner russiske myndigheter måtte ha overfor Norge er det vanskelig for oss å vite, men vi synes det er rimelig å anta at valg av instrumenter også betinges av hvilke kostnader de har for Russland. Selv om grenseregimet på russisk side var blitt liberalisert, er det liten tvil om at det lokale FSB fortsatt hadde et sterkt kontrollønske. Vi vil mene, med stor grad av rimelighet, at russiske myndigheter - og da først og fremst de myndighetene som har som oppgave å kontrollere grenseområdet - ikke ønsker store ansamlinger mennesker med usikker identitet og begrensede eller tvilsomme oppholdstillatelser, på sine enemerker. Situasjonen som oppsto høsten 2015, der mellom 1000 til 1500 migranter kunne oppholde seg i grensebyene Zapoljarnyj og Nikel, var med andre ord en tilstand som stred mot russiske sikkerhetshensyn. På mer generell basis er flyktningstrømmen til og gjennom Russland etterhvert blitt tatt opp som en sikkerhetsutfordring på høyeste politiske nivå (Putin 2016a).

Men hvorfor gjorde da ikke russiske myndigheter noe for å stoppe strømmen? Vi tror mye av forklaringen ligger i hvordan det russiske byråkratiet fungerer. På den ene siden er det regelstyrt, med svært lite handlingsrom i de underliggende etatene. Alle tjenestemenn som er interessert i å beholde sin stilling, bør passe på å følge reglene til punkt og prikke. Dette gir et stivbent byråkrati. Reglene kan endres, men det er en omstendelig prosess. Liberaliseringen av grenseregimet var oppfattet og gjennomført av tjenestemenn i de russiske grensestyrkene. Det ser vi av gjentatte uttalelser om at migranter på vei til Norge ikke kunne stoppes - bare kontrolleres. På den andre siden er Russland sentralisert og med stor makt samlet hos presidenten. Hvis det er nødvendig, kan det skjæres igjennom med forordninger på kort varsel (Sakwa 2010). Men det skal mye til før en sak kommer opp på dette beslutningsnivået. Dessuten må det - sett fra russisk side - ha vært nærliggende å tenke at det var en annen part som hadde de beste muligheter til å påvirke asylantstrømmen - nemlig Norge.

Den voldsomme økningen i migrantstrømmen kom helt uventet på Russland. Det samme var tilfelle i Norge. Vi vil hevde, med basis i bekrivelsen av utviklingen i 
norske prosedyrer ovenfor, at man fra norsk side har drevet et ganske liberalt innreiseregime på grensen i nord. Det opprinnelige skrivet fra politimesteren i ØstFinnmark som ble overlevert migranter mens de ennå sto på russisk side av grensen, framstår som uegnet til å stoppe noen som måtte ønske seg til Norge uten visum. Det inneholdt ingen eksplisitte advarsler om at visum til Norge var en forutsetning for innreise. I stedet ble mottakeren av skrivet orientert om hvordan han eller hun skulle forholde seg for å søke visum. Selv etter at flyktningstrømmen i Sør-Europa tiltok var det ikke mange som tenkte på at Pasvik i Finnmark utgjorde en flik av Schengenområdets yttergrense.

En sannsynlig årsak til den norske motviljen mot å stramme inn formuleringen, er at norske myndigheter ikke ønsket å gi russiske grensekontrollører et implisitt medansvar for norsk asylpolitikk. Man ville ikke sette seg i en situasjon der man kunne anklages for å oppmuntre russiske myndigheter til å begrense migranters muligheter til å søke asyl i Norge, noe som ville vært politisk kontroversielt. Samtidig kostet den liberale praksisen på grensen i nord lite så lenge «den arktiske ruten» var nærmest ukjent. Men den store tilstrømningen av flyktninger høsten 2015 eksponerte svakheten i den norske praksisen. Som vi så ble den, og da først og fremst brevet fra norske myndigheter til tredjelands borgere uten visum til Norge, $\mathrm{i}$ løpet av noen korte uker i november endret i samsvar med hvordan Russland lenge hadde ment den burde være. Holdningen på russisk side hadde da vært konstant siden 2012 - det som endret seg var den norske praksisen ved grensen utløst av en ny norsk asylpolitikk.

\section{De russisk-finske grenseovergangene}

Forholdene på grensen mellom Russland og Finland ble trukket inn i debatten fordi utviklingen ved de to finsk-russiske grenseovergangene i nord - Salla og RajaJooseppi - tilsynelatende skilte seg fra Storskog. Etter hvert som strømmen over grensen til Norge økte, ble det merkverdige i at man ikke så en tilsvarende strøm over grensen til Finland påpekt fra flere hold. Dette bygget opp under argumentasjonen om at strømmen til Norge var styrt av russiske myndigheter. Finland ble angivelig behandlet annerledes fordi landet ikke var NATO-medlem.

I norsk presse ble det rapportert at det på grensen mellom Russland og Finland var et strengere regime ( $V G$ 2015). Det var åpenbart langt færre asylsøkere som forsøkte å komme over grensestasjonen ved Salla. Mye kunne tyde på at mennesker uten visum til Finland ble holdt borte fra grensen av russiske grensemyndigheter.

Mot slutten av 2015 endret situasjonen seg, tilsynelatende som en konsekvens av innstrammingen på den norsk-russiske grenseovergangen. Mens trafikken over Storskog tok en brå slutt i desember, skjedde det motsatte over grensen til Finland. Migranter fløy fortsatt til Murmansk, men i stedet for å sette kurs mot Nikel og Storskog dro de nå til Kandalaksja, som ligger 230 kilometer sør for flyplassen i Murmasji. Der kjøpte de gamle biler til en gjennomsnittspris av 20000 rubler, noe som tilsvarte omkring 200 USD per person hvis fire til fem passasjerer deler på utgiften. Fra Kandalaksja kjørte de til finskegrensen ved Salla - som ligger 
200 kilometer vest for Kandalaksja. Noen reiste også direkte fra St. Petersburg eller Moskva med bil til denne grensestasjonen (Murmanskij Vestnik 2016). Gitt avstanden fra grenseovergangene til nærmeste bosetning samt vinterforholdene var det heller ikke hensiktsmessig å sykle. ${ }^{7}$ I løpet av en måneds tid søkte 1000 mennesker asyl på grensen til Finland (Bjon 2016).

Finske spekulasjoner og teorier om hvorfor dette skjedde viser en påfallende likhet med det vi har referert fra Storskog-situasjonen i Norge. Også i Finland ble det hevdet at russiske myndigheter organiserte flyktningstrømmen (Grüne 2016). En russisk grensevakt fortalte til det finske nyhetsbyrået $F N B$ at FSB sammen med distriktsadministrasjonen i Kandalaksja organiserte reisene mot grensen. Barnefamilier ble gitt prioritet, het det (Hufvudstadsbladet-hbl.fi 2016a). I følge finske medier innførte Russland en ny praksis ved å unnlate å kreve Schengen-visum fra personer som ønsket å krysse grensen. Dette ble også hevdet av finske myndighetsrepresentanter. Spørsmålet ble satt på spissen i et møte mellom Finlands president Sauli Niinistö og Russlands statsminister Dmitrij Medvedev 12. februar 2016. Niinistö mente å kunne se at russernes regime hadde endret seg fra det som tidligere var praksis: «(...) over lang tid har det der [på grensen] på gjensidig grunnlag fungert slik at det uten visum har vært umulig å reise fram til grensen» (Portal pravitelstva Rossii 2016). Dette står i kontrast til Medvedevs uttalelse: «(. . .) vi kan ikke stanse dem. Det finnes en europeisk menneskerettskonvensjon vi har sluttet oss til» (Medvedev 2016).

Vi har ikke fått informasjon om det at det skulle foreligge en avtale mellom Finland og Russland om en restriktiv praksis som innebærer at tredjelands borgere uten visum til Finland skulle nektes adgang til grenseovergangene. Snarere virker det som om det har eksistert en finsk forventning om at Russland ville stoppe migranter uten visum. Dette likner på det vi har redegjort for ovenfor: en norsk forventning om et strengt russisk grenseregime som ikke kan festes i formelle dokumenter. Begge steder har grenseregimet vært noe uklart, og det ble og blir anvendt mer eller mindre formelle praksiser som avtales på lokalt nivå - mellom grensekommisærene og tilsvarende organer.

Finland og Russland gjennomførte i midten av februar 2016 forhandlinger mellom berørte myndigheter, inkludert ledelsen i FSB (Hufvudstadsbladet-hbl.fi 2016b). I slutten av februar 2016 tørket også strømmen over Salla inn. Da hadde over tusen migranter krysset grensen siden begynnelsen av året (Hufvudstadsbladethbl.fi 2016c). På dette tidspunktet hadde også president Putin uttalt seg - i generelle ordelag - om flyktningstrømmen i en tale til ledelsen i FSB: «Det er nødvendig å forsterke kontrollen med strømmene av flyktninger som reiser inn i Russland så vel som i transitt til land i Europa» (Putin 2016b).

Etter at russiske medier meldte at grensepasseringspunktet var stengt for «migranter fra Midtøsten» (Nord-Nerws.ru 2016b), sendte det finske Gränsbevakningsväsenet ut en kommentar: «I russiske massemedia skrives det at Finland har stengt grensepasseringspunktet Salla for flyktninger i tre døgn. Denne informasjonen samsvarer ikke med virkeligheten (...). Fra Russland til Finland gjennom

${ }^{7}$ Det ble imidlertid brukt sykler over grensestasjonen ved Raja-Jooseppi (Pedersen 2015). 
grensepasseringspunktene Salla og Raja-Jooseppi i Lappland har det de to siste døgn ikke kommet en eneste utlending (...). [Den finske] grensetjenestens ønske har vært at den russiske føderasjon ikke slipper fram de utlendinger som ikke har grunnlag for innreise til Finland (...). De siste begivenheter viser at russiske myndigheter nå handler i samsvar med forventningene til den finske grensetjenestens seksjon for Lappland». Uttalelsen ble sitert i russiske medier (TASS 2016).

Vi vil hevde at Gränsbevakningsväsenets kommentar langt på vei hadde samme funksjon som uttalelsen fra statsminister Solberg om at norske myndigheter ikke ønsket at Russland slapp migranter «uten Schengen-visum» fram til grensen (se ovenfor). Som i det nye skrivet fra norske grensemyndigheter som nå gis til russisk grensevakt når asylsøkere står ved Boris Gleb, ga også finske myndigheter et tydelig uttrykk for hva de ønsket at russiske myndigheter skulle gjøre. Det som før var implisitt var nå blitt eksplisitt, både fra norsk og finsk myndighetshold. Hvilke utslag, om noen, dette gir i konkrete reglementer og instrukser på russisk side gjenstår å se. Allerede 9. mars 2016 kunne imidlertid sjefen for den russiske migrasjonstjenesten konstatere at 65 utenlandske borgere med ambisjoner om å nå fram til Schengen-området gjennom Murmansk fylke på «ulovlig vis», var internert i «spesielle institusjoner». Dette skjedde, stadig ifølge migrasjonstjenestens leder, i samarbeid «med finske partnere» (Khibiny.com 2016).

\section{Norge og Finland - små forskjeller}

Det mest påfallende $\mathrm{i}$ de to mer eller mindre parallelle historiene, er sammenfallet mellom Norges og Finlands respektive erfaringer og reaksjoner. Det finnes visse ulikheter, som tidspunktet for når flyktningene begynte å komme for alvor. Hovedårsaken til at det $\mathrm{i}$ begynnelsen kom færre asylsøkere til den finsk-russiske grensen enn den norsk-russiske, kan ha hatt sin bakgrunn i noe så prosaisk som beliggenhet. Mens det ligger hotell og andre innkvarteringsmuligheter i Nikel og Zapoljarnyj mellom 40 og 60 kilometers veistrekning fra Storskog, er den tilsvarende avstanden fra Salla til nærmeste overnattingssted i Kandalaksja rett i overkant av 200 kilometer. Fra Raja-Jooseppi til nærmeste russiske bosetning er det 160 kilometer (iFinnmark 2015). Den finske ruten ble virkelig interessant først da overgangen til Norge ble mer eller mindre stengt.

Det kan ikke utelukkes at noen har «markedsført» ruten til Norge mer aggressivt. Men at russiske myndigheter som sådan skulle stå bak, finner vi ingen indikasjoner på og heller ingen sterk logikk bak. At tjenestemenn kan ha vært med på å få migranter ut av regionen når de først var der, slik det ble meldt fra Finland, endrer ikke dette bildet. Det kan sees som et bidrag til å løse problemet på regionalt nivå. På den ene siden kan sikkerhetsmessige hensyn ligge bak, slik vi har redegjort for. En annen, men vel så opplagt russisk motivasjon for å tilrettelegge for at migrantene kom seg videre, er at flyktninger, på samme måte som i Norge og Finland, ble opplevd som en byrde for det russiske samfunnet. For sentralmyndigheten i Moskva er det likevel reduksjon av trafikken inn til Russland som framstår som viktigst (Putin 2016a). 
Reaksjonene på finsk side var også svært like det vi observerte i Norge: Spekulasjoner om overlagte russiske manipuleringer av flyktningstrømmen fikk stor plass, uten at det forelå noen overbevisende dokumentasjon for at noe slikt skulle ha skjedd. Dette kan forstås i lys av nok en finsk-norsk parallell, nemlig forventningen om at russiske grensemyndigheter var restriktive nok til å stoppe strømmen av migranter. Denne forventningen kan muligens spores tilbake til tidligere praksis, kanskje så langt tilbake som før Sovjetunionens sammenbrudd, men den har liten eller ingen forankring i dagens faktiske forhold. Som vi har redegjort for, hadde russiske grensemyndigheter hverken et juridisk grunnlag for eller egeninteresse av å holde migrantene tilbake på russisk territorium når de først var kommet inn i grenseområdet - tvert imot.

Både i Finland og Norge var det stor oppstandelse over den plutselige tilstrømningen av asylsøkere. I begge land var det bekymring for at mottaksapparatet ikke skulle være i stand til å håndtere volumet. I takt med at denne bekymringen styrket seg, ble villigheten begge steder til å gå i dialog med russiske myndigheter og ikke minst justere egne praksiser ved grensen, langt større. Den politiske aksepten for en strammere politikk ble også større. Det er altså lite eller ingenting som tyder på at flyktningstrømmen kom som et resultat av endringer i russisk praksis. Tvert imot framtvang situasjonen endringer $i$ finsk og norsk praksis. Endringene kom i form av eksplisitte uttalelser og i Norges tilfelle også i form av den omtalte tilstrammingen i brevet som ble gitt til tredjelands borgere uten visum til Norge da de fremdeles befant seg ved Boris Gleb. Finland inngikk en avtale med Russland som trådte i kraft 10. april 2016 med varighet i 180 dager som reserverte de to grenseovergangene $i$ nord for finske, russiske og hviterussiske ${ }^{8}$ borgere, noe som effektivt ville forhindre nye asylstrømmer over disse grensepasseringspunktene (Inrikesministeriet 2016).

\section{Konklusjon}

Hvis vi så returnerer til spørsmålet vi stilte innledningsvis: Foreligger det andre og mer plausible forklaringer på hvorfor et uvanlig høyt antall flyktninger søkte seg til Storskog høsten 2015 enn at det var et ledd i russisk hybridføring mot Norge? Svaret må på bakgrunn av ovenstående gjennomgang være et klart ja. Hvis man ser på praksisen som var etablert før endringene i norske og finske tilnærminger ble framprovosert, er det ingenting som tyder på at russiske grensemyndigheter foretok seg noe utenom det vanlige. Den russiske praksisen endret seg ikke i løpet av 2015. Tvert imot eksisterte det et russisk press over tid for at den norske praksisen skulle bli mer restriktiv, noe den til slutt ble. Vi hevder også at den store strømmen av flyktninger gjennom dette området var negativt for Russland sikkerhetsmessig og slett ikke ville vært noe kostnadsfritt virkemiddel, dersom man skulle hatt et ønske om å skape problemer for Norge.

\footnotetext{
${ }^{8}$ Russland og Hviterussland har en passunion. Sistnevnte omfattes derfor av nevnte avtale med Finland.
} 
Som vi har sett ovenfor er det ikke forskjellene, men likhetene, som er det slående når man sammenlikner den norske og den finske opplevelsen av flyktningstrømmen. Det faktum at Finland står utenfor NATO synes ikke å ha noen som helst relevans - Finland ble på lik linje med Norge stilt overfor en plutselig tilstrømming av asylsøkere via den arktiske ruten. Den viktigste forskjellen var at dette inntraff noe senere i Finland, etter at den norsk-russiske grenseovergangen i praksis ble stengt for asylsøkere.

Sett under ett: Den mest sannsynlige forklaringen på den plutselige asylstrømmen var ganske enkelt at migranter fra ulike deler av verden, med varierende grad av beskyttelsesbehov, ble klar over muligheten for å komme seg til Schengen-området på en billigere og ikke minst mindre risikofylt måte enn tidligere.

\section{Om artikkelen}

Rowes bidrag inngår i prosjektet (Des-)informasjon på russisk, finansiert av Forsvarsdepartementets tilskuddsordning til akademiske institusjoner og universitetsmiljø innen sikkerhets- og forsvarspolitisk forskning.

\section{Litteratur}

Aftenposten (2014) «Frykter at russere sniker seg inn i Norge». 15. mai. Tilgjengelig på www.aftenposten.no/ nyheter/iriks/Frykter-at-russere-sniker-seg-inn-i-Norge-7580106.html. Lesedato 15. mars 2016.

Aftenposten (2015a) «Putin straffer Norge med asylsøkere». 23 oktober. Tilgjengelig på www.aftenposten.no/ nyheter/uriks/Putin-straffer-Norge-med-asylsokere-8214587.html. Lesedato 11. mai 2016.

Aftenposten (2015b) «Asylsøkere sykler fra Russland til Norge». 27. august. Tilgjengelig på www.aftenposten. no/nyheter/iriks/Asylsokere-sykler-fra-Russland-til-Norge-8140328.html. Lesedato 11. mai 2016.

Bjon, Sylvia (2016) «Orpo: Vi utökar samarbetet med Ryssland». Hufvudstadsbladet (hbl.fi) 27. januar. Tilgjengelig på www.hbl.fi/artikel/orpo-vi-utokar-samarbetet-med-ryssland/. Lesedato 19. mai 2016.

Dagsrevyen (2015) NRK 10. november. Tilgjengelig på https://tv.nrk.no/serie/dagsrevyen/NNFA19111015/10$11-2015 \# \mathrm{t}=1 \mathrm{~m} 34 \mathrm{~s}$. Sett 25. februar 2016.

Etterretningstjenesten (2016) «Fokus 2016 - Etterretningstjenestens vurdering av aktuelle sikkerhetsutfordringer». Oslo: Etterretningstjenesten. Tilgjengelig på https://forsvaret.no/fokus. Lesedato 11. mai 2016.

FSB (2006) «Prikaz Federalnoj sluzjby bezopasnosti Rossijskoj Federatsii ot 2 ijunja 2006 g. N 240. O predelakh pogranitsjnoj zony na territorii Murmanskoj oblast». Rossijskaja gazeta 4. juli.

FSB (2007) «Prikaz Federalnoj sluzjby bezopasnosti Rossijskoj Federatsii ot 10 maja 2007 g. N 230 “O vnesenii izmenenija v prikaz FSB Rossii ot 2 ijunja 2006 g. N 240"». Rossijskaja gazeta 8. juni.

FSB (2008) «Prikaz FSB ot 1 oktjabrja 2008 g. N 474 “O vnesenii izmenenija v prikaz FSB Rossii ot 2 ijunja 2006 g. N 240 i priznanii utrativsjim silu prikaza FSB Rossii ot 10 maja 2007 g. N 230”». Tilgjengelig på www.garant.ru/products/ipo/prime/doc/94143/\#ixzz48SZ1ArwZ. Lesedato 11. mai 2016.

FSB (2012) «Prikaz Federalnoj sluzjby bezopasnosti Rossijskoj Federatsii ot 15 oktjabrja 2012 g. N “Ob utverzjdenii Pravil pogranitsjnogo rezjima"». Rossijskaja gazeta 21. desember.

Gerasimov, Valerij (2013) «Tsennost nauki v predvidenii». Voenno-promysjlennyj kurer 8: 1-3.

Giles, Ken (2016) Russia's New Tools for Confronting the West: Continuity and Innovation in Moscow's Exercise of Power. London: Chatham House.

Grenseboeravtalen (2010) «Avtale mellom Kongeriket Norges regjering og Den Russiske Føderasjons regjering om forenkling av gjensidige reiser for grenseboere i Kongeriket Norge og Den Russiske Føderasjon». Tilgjengelig på www.regjeringen.no/globalassets/upload/jd/vedlegg/grenseboeravtale_nor.pdf. Lesedato 15. mars 2016 .

Grüne, Yrsa (2016) «Ryssland väljer alltför selektivt». Hufvudstadsbladet (hbl.fi) 18. februar. Tilgjengelig på www.hbl.fi/artikel/ryssland-valjer-alltfor-selektivt/. Lesedato 19. mai 2016.

Hønneland, Geir \& Anne-Kristin Jørgensen (1999) Integration vs. Autonomy: Civil-Military Relations on the Kola Peninsula. Aldershot: Ashgate. 
Hufvudstadsbladet-hbl.fi (2016a) «Rysk gränsbevakare: FSB organiserar flyktingar till gränsen». 23. januar. Tilgjengelig på www.hbl.fi/artikel/rysk-gransbevakare-fsb-organiserar-flyktingar-till-gransen/ Lesedato 19. mai 2016.

Hufvudstadsbladet-hbl.fi (2016b) «HS: Orpo förhandlade om flyktingar med FSB». 15. februar. Tilgjengelig på www.hbl.fi/artikel/hs-orpo-forhandlade-om-flyktingar-med-fsb/. Lesedato 19. mai 2016.

Hufvudstadsbladet-hbl.fi (2016c) «Inga asylsökande vid gränsen i östra Lappland». 2. mars. Tilgjengelig på www. hbl.fi/artikel/inga-asylsokande-vid-gransen-i-ostra-lappland/. Lesedato 19. mai 2016.

Inrikesministeriet (2016) «Trafikbegränsningar vid gränsövergångsställena i Salla och Raja-Jooseppi träder i kraft 10.4». Pressemeddelande 8 april. Tilgjengelig på www.intermin.fi/sv/aktuellt/nyheter/1/1/trafik begransningar_vid_gransovergangsstallena_i_salla_och_raja-jooseppi_trader_i_kraft_10_4_66911. Lesedato 12. mai 2016.

Justis- og beredskapsdepartementet (2015) «Rutiner for rask håndtering av personer som ankommer over norskrussisk landegrense (Storskog) uten gyldig visum eller annen gyldig innreisetillatelse til Norge». Instruks til Politidirektoratet fra Justis- og beredskapsdepartementet. 24. november.

Karlsen, Geir Håkon (2015) «Putins plan». Dagens Neringsliv 15. mai.

Khibiny.com (2012) «Pogranitsjnaja sluzjba FSB ustanavlivaet esjtsje odin sjlagbaum na granitse c Norvegiej» 20. januar 2012. Tilgjengelig på www.hibiny.com/news/archive/30738. Lesedato 11. mai 2016.

Khibiny.com (2016) «V Murmanskoj oblasti zaderzjany 65 bezjentsev, pytavsjikhsia vekhat v Finljandiju». 9. mars. Tilgjengelig på www.hibiny.com/news/archive/100912. Lesedato 12. mai 2016.

Kommersant (2015a) «Sirijskie bezjentsy vstali na Kolskij put». 25 september.

Kommersant (2015b) «Norvegija khotsjet vernut sirijskikh bezjentsev Rossii». 15. oktober.

Kommersant (2016) «Migrantov iz Sirii otpavljali v Norvegiju po delovym vizam». 27. januar.

Medvedev, Dmitij (2016) «Intervju Dmitrija Medvedeva nemetskoj gazete «Handelsblatt». 11. februar. Tilgjengelig på http://government.ru/news/21765/. Lesedato 12. mai 2016.

Murmanskij Vestnik (2008) «Pogranzona: sjag vpered na tri goda nazad». 13. desember.

Murmanskij Vestnik (2015a) «K lutsjsjej zjizni na velosipede». 8. september.

Murmanskij Vestnik (2015b) «Koridor nadezjdy». 24 september.

Murmanskij Vestnik (2015c) «Potok bezjentsev s Blizjnego Vostoka tsjerez Zapolare "pomenjal ruslo" s Norvegii na Finljandiju». 18. desember 2015.

Murmanskij Vestnik (2016) «Migranty massovo skupajut v Zapolare masjiny, no mnogie ezdjat bez prav». 10. februar.

Nord-News.ru (2015) «Dokumenty passazjirov, letjasjtsjikh v Murmansk iz Moskvy, tsjtsjatelno proverjajut sotrudniki UFMS». 13. november. Tilgjengelig på www.nord-news.ru/news/2015/11/13/?newsid=79193. Lesedato 12. mai 2016.

Nord-News.ru (2016a) «V Murmanske arestovali podozrevaemogo v organizatsii nelegalnykh perevozok bezjentsev v Skandinaviju». 26. februar. Tilgjengelig på www.nord-news.ru/news/2016/02/26/? newsid $=81246$. Lesedato 12 . mai 2016.

Nord-News.ru (2016b) «V Kandalaksje bezjentsy trebujut vypustit ikh v Finljandiju». 2. mars. Tilgjengelig på www.nord-news.ru/news/2016/03/02/?newsid=81351. Lesedato 12. mai 2016.

NRK Finnmark (2015) «Mener Norge selv kunne stoppet asylstrømmen». 10. november. Tilgjengelig på www. nrk.no/finnmark/mener-norge-selv-kunne-stoppet-asylstrommen-1.12647229. Lesedato 25 . februar 2016.

Pedersen, Ole-Tommy (2015) «Da asyltrafikken økte her, løste grensekapteinen det med én telefon til Russland». ifinnmark 10. desember 2015. Tilgjengelig på www.ifinnmark.no/nyheter/asylsokere/flykt ninger/da-asyltrafikken-okte-her-loste-grensekapteinen-det-med-n-telefon-til-russland/s/5-81-170612.

Lesedato 12. mai 2016.

Portal pravitelstva Rossii (2016) «Vstretsja Dmitrija Medvedeva s Prezidentom Finljandii Sauli Niinistö». 12. februar. Tilgjengelig på http://government.ru/news/21769/. Lesedato 12. mai 2016.

Pynnöniemi, Katri \& András Rácz (red.) (2016) Fog of Falsehood: Russian Strategy of Deception and the Conflict in the Ukraine. FIIA Report 45. Helsinki: Finnish Institute of International Affairs.

Putin, Vladimir (2016a) «Zasedanie Soveta Bezopasnosti». 31. mars. Tilgjengelig på http://kremlin.ru/events/ president/news/51618. Lesedato 12. mai 2016.

Putin, Vladimir (2016b) «Zasedanie kollegii Federalnoj sluzjby bezopasnosti» 26. februar. Tilgjengelig på http://kremlin.ru/events/president/news/51397. Lesedato 12. mai 2016.

Reuters (2015) «On Arctic Tip of Europe, Syrian Migrants Reach Norway by Bike». 3. september. Tilgjengelig på www.reuters.com/article/us-europe-migrants-arctic-idUSKCN0R325N20150903. Lesedato 11 mai 2016. 
Rowe, Lars \& Geir Hønneland (2010) «Norge og Russland: Tilbake til normaltilstanden» Nordisk Østforum 24 (2): 133-147.

Sakwa, Richard (2010) «The Dual State in Russia». Post-Soviet Affairs 26 (3): 185-206.

Stormark, Kjetil (2015) «Flyktningestrøm trolig russisk hybridkrig». Tilgjengelig på www.aldrimer.no/ flyktningestrom-er-trolig-russisk-hybridkrig. Lesedato 15. april 2016.

TASS (2015) "Glava MID korolevstva: Norvegija i RF nuzjno dostitsj vzaimoponimanija v voprose o bezjentsakh». 11. november. Tilgjengelig på http://tass.ru/mezhdunarodnaya-panorama/2426533. Lesedato 12. mai 2016.

TASS (2016) «Finljandija ne zakryvala granitsu s Rossiej na pogranpunkte Salla iz-za bezjentsev». 3. mars. Tilgjengelig på http://tass.ru/mezhdunarodnaya-panorama/2714654. Lesedato 12. mai 2016.

Tilbaketakingsavtalen (2007) «Avtale mellom Kongeriket Norges Regjering og Den russiske føderasjons Regjering om tilbaketaking av 8. juni 2007». Tilgjengelig på www.udiregelverk.no/no/rettskilder/bilateraleavtaler/2007-06-081/. Lesedato 25. februar 2016.

Vedomosti (2016a) «Bolsje, tsjem osjibka». 17. mars.

Vedomosti (2016b) «Migatsionnaja sluzjba mozjet byt likvidirovana, a ee polnomotsjija podeleny». 31. mars.

Vedomosti (2016c) «Putin perevel FSKN i FMS v podtsjinenie MVD». 5. April.

$V G$ (2015) «Bare 35 asylsøkere fra Russland til Finland i år». 21. oktober.

Zakon (1993) «O Gusudarsvennoj granitse Rossijskoj Federatsii» 1 aprelja 1993 g. N 4730. Tilgjengelig på http://base.garant.ru/10103372/\#. Lesedato 11. mai 2016.

Østfinnmark politidistrikt (2012) «Brev fra Politiet til “den det måtte gjelde”». Datert 3. august 2012. En kopi av dokumentet befinner seg hos forfatterne.

Østfinnmark politidistrikt (2015) «Søkt asyl i Østfinnmark politidistrikt 2003-2015». Udatert dokument vedlagt e-post til NRK, 7. april 2015, i forfatternes arkiv. 